\title{
Tachycardias in neonates
}

Sandra Cerar, Miroslav Elek

\section{Izvleček}

Pri novorojenčkih neredko prihaja do motenj srčnega ritma. Pojavljajo se lahko pri otrocih s strukturno normalnim srcem in pri otrocih s prirojenimi boleznimi srca. Najpogostejša tahikardna motnja srčnega ritma, ki jo pri novorojenčkih moramo zdraviti, je nadprekatna tahikardija, ki ji sledi atrijsko plapolanje. Mehanizma nastanka tahikardij sta povečana prevodnost preko krogotoka s ponovnim vstopom (angl. re-entry circuits) ali povečana avtomatičnost sprožilnega žarišča. Dejavniki tveganja za motnje srčnega ritma (prirojena srčna napaka, nedonošenost, elektrolitske motnje, zdravila, okužbe, povišana telesna temperatura) so prisotni le pri manjšini novorojenčkov. Klinično se tahikardija kaže z nespecifičnimi in pogosto diskretnimi znaki, kot so odklanjanje hranjenja, letargija, razdražljivost, tahipneja, bledica, cianoza, potenje in stokanje. Pri nekaterih lahko pride do hude cirkulatorne odpovedi. Aritmije so relativno pogoste pri otrocih $v$ enoti za intenzivno medicino $v 24$ urah po srčni operaciji. Zdravljenje vključuje vagalne manevre, intravensko dajanje adenozina, uporabo antiaritmičnih zdravil in elektrokonverzijo. V prispevku opisujemo posamezne vrste tahikardij in načela zdravljenja. Opisujemo klinična primera novorojenčkov s tahikardijo.

Ključne besede: nadprekatna tahikardija, atrioventrikularna re-entry tahikardija, atrijsko plapolanje, motnja srčnega ritma, novorojenček, patofiziologija, zdravljenje.

\section{Abstract}

Cardiac arrhythmias often occur in the neonatal period. They can occur in children with a structurally normal heart as well as in children with congenital heart diseases. The most common pathological tachycardia in the newborn is supraventricular tachycardia with a narrow QRS complex, followed by atrial flutter. The mechanisms for the development of tachyarrhythmias can be enhanced conduction with the presence of re-entry circuits or enhanced automaticity with triggered foci. Risk factors for arrhythmias include congenital cardiac malformations, prematurity, electrolyte disorders, exposure to proarrhytmogenic ? proarrhythmic drugs, infections and fever, although they are present only in the minority of neonates. The clinical presentation may be subtle and non-specific; it may include refusal to feed, lethargy, irritability, tachypnoea, pallor, cyanosis, sweating and grunting. Some arrhythmias can lead to severe circulatory failure. Arrhythmias are relatively common in the paediatric cardiac intensive care unit in patients within 24 hours after heart surgery. and may cause significant hemodynamic instability and compromise. The acute management includes the use of vagal manoeuvres, intravenous adenosine, antiarrhythmic drugs and cardioversion. This review aims to provide a framework for the diagnosis and management of neonatal tachycardias. Two case reports of neonatal tachycardia are described.

Key words: supraventricular tachycardia, atrioventricular re-entry tachycardia, atrial flutter, arrhythmia, neonate, pathophysiology, management. 


\section{Uvod}

Postavitev diagnoze in zdravljenje motenj srčnega ritma pri novorojenčku je za zdravnika velik izziv. Med razvojem od ploda do odraslega človeka se spremembe $v$ anatomiji in fiziologiji srca odražajo tudi v različnih značilnostih v elektrokardigramu (EKG). Za ustrezno tolmačenje zapisa moramo poznati določene zakonitosti in se opirati na referenčne vrednosti za novorojenčke (1-3). Spremembe srčnega ritma, kot so prezgodnji atrijski utripi ali prezgodnji prekatni utripi, so lahko fiziološko stanje $v$ tem razvojnem obdobju in zato normalne različice. Pojavnost nadprekatnih tahikardij je po navedbah v literaturi različna in znaša 1/250-25.000 otrok $(3,4)$. Višjo pojavnost gre $v$ zadnjem času delno pripisati tudi bolj učinkovitemu odkrivanju bolnikov.

Aritmije so relativno pogoste pri otrocih $v$ enoti za intenzivno medicino $v$ 24 urah po srčni operaciji. Večinoma so prehodne in ne vplivajo na hemodinamsko stanje, a pri nekaterih lahko pride do hude cirkulatorne odpovedi (2). Mehanizem, potek in zdravljenje motenj srčnega ritma so v obdobju novorojenčka in dojenčka dokaj enaki, a se razlikujejo od motenj srčnega ritma pri večjih otrocih.

\section{Definicija nadprekatnih tahikardij in razvrstitev}

Nadprekatna tahikardija (supraventrikularna tahikardija, SVT) je pospešen srčni ritem, ki je enak ali višji od 98. percentila za starost, abnormni prožilni mehanizem pa izvira pred razcepiščem Hissovega snopa (3).

Glede na navedeno definicijo lahko med SVT v obdobju novorojenčka prištevamo atrio-ventrikularno re-entry tahikardijo (AVRT), atrio-ventrikularno nodalno re-entry tahikardijo (AVNRT), atrijsko plapolanje (angl. atrial flutter, AFL), atrijsko ektopično tahikardijo $(A E T)$ in junkcijsko ektopično tahikar- dijo (JET). Navedene tahikardije opisujemo v nadaljevanju. Razlikujemo jih lahko glede na značilnosti v EKG in $z$ adenonozinskim testom; slednji pomaga pri diferencialnem diagnosticiranju oziroma razlikovanju med SVT ter sinusno tahikardijo in ventrikularnimi tahikardijami (VT) (3).

\section{Mehanizem nastanka nadprekatnih tahikardij in diferencialna diagnoza}

Za lažje razumevanje nastanka tahikardij srce razdelimo na tri dele: preddvore (atrije), prevodni sistem in prekate (ventrikle). Preddvora in prekata sta med seboj električno izolirani enoti, ki sta povezani preko prevodnega sistema. Atrio-ventrikularni vozel (AV vozel), Hissov snop in Purkinejeva vlakna so specializirana tkiva, ki prenašajo električni impulz od preddvorov do prekatov. V AV vozlu se električni impulz sprva upočasni in s tem omogoči polnitev prekatov, nato pa se učinkovito prevede $v$ prekate $z$ namenom njihovega usklajenega krčenja (1). Prevodni sistem je edina fiziološka vez med preddvori in prekati; za morfološko ločenost miokarda pa skrbi vezivni obroč (lat. anulus fibrosus), ki dozoreva še po rojstvu.

SVT lahko nastane po mehanizmu povečane prevodnosti preko krogotoka s ponovnim vstopom (angl. re-entry circuits), za katerega morata poleg normalne prevodne poti obstajati tudi akcesorna (dodatna) prevodna pot, ki povezuje preddvor s prekatom, in enosmerni blok prevajanja v eni od obeh poti (5). Obstoj oziroma nastanek akcesorne prevodne poti je lahko posledica patološkega dozorevanja fibroznega obroča (6). SVT z mehanizmom ponovnega vstopa so AVRT, ki se pojavlja v $80 \%$ neonatalnih primerov, AVNRT, ki se pojavlja v $5 \%$ neoantalnih primerov, in AFL, pri katerem se mehanizem ponovnega vstopa nahaja znotraj preddvora in govorimo o »mikro re-entry« mehanizmu.
Drug mehanizem nastanka SVT je povečana avtomatičnost, ki je odraz avtonomne ponavljajoče se depolarizacije miocitov s frekvenco, ki je višja od normalne. Mehanizem v obliki povečane avtomatičnosti se pojavlja v $15 \%$ neonatalnih primerov $(1,2)$. Po tem mehanizmu najpogosteje nastajajo naslednje SVT: atrijska ektopična tahikardija (AET), junkcijska ektopična tahikardija (JET) (7) in sinusna tahikardija. Glavna značilnost, po kateri tahikardije s ponovnim vstopom razlikujemo od tahikardij zaradi povečane avtomatičnosti, je njihov nenaden začetek ali konec (7). Pri mehanizmu povečane avtomatičnosti je značilen fenomen ogrevanja in ohlajanja (1). Razumevanje mehanizma nastanka aritmij je ključno pri izbiri zdravljenja (2).

\section{Opis posameznih tahikardij v obdobju novorojenčka}

\section{Atrio-ventrikularna re-entry tahikardija (AVRT)}

Pri AVRT poteka akcesorna pot zunaj AV vozla (8). Anterogradno prevajanje poteka iz preddvorov do prekatov preko AV vozla, nato pa retrogradno iz prekatov $v$ preddvore po akcesorni poti. $V$ EKG zapisu je kompleks QRS ozek ( $<80$ $\mathrm{ms}$ ), saj se prekati depolarizirajo preko prevodnega sistema, po katerem je prevajanje najhitrejše. Za kompleksom QRS je viden retrogradni val $P$, saj traja nekaj časa, da se impulz prevede iz prekatov nazaj navzgor po akcesorni poti (1). Značilen je kratek interval RP $(3,8)$.

Podtip AVRT je Wolf-Parkinson-Whiteov sindrom (sindrom WPW), katerega patognomoničen znak je lahko znak preekscitacije - val delta (položno dvigovanje spojnice do kompleksa QRS v EKG zapisu v sinusnem ritmu) (8). Pri WPW se električni signali lahko prevajajo naprej in nazaj po akcesorni prevodni poti. Pri novorojenčkih in dojenčkih je najpogostejši ortodromni krogotok AVRT, pri katerem prevajanje poteka navzdol preko AV vozla in nazaj do atri- 
jev po akcesorni poti. V EKG zapisu ni znakov preekscitacije. Mnogo redkejša je antidromna pot, kjer prevajanje navzdol najprej poteka po akcesorni poti, nato pa se impulz vrača nazaj navzgor po prevodnem sistemu (1). Ker je zaradi hitrejšega prevajanja po akcesorni poti depolarizacija prekatov hitrejša in s tem tudi bolj zgodnja, se v EKG zapisu odraža s prisotnostjo vala delta in posledično širšim kompleksom QRS (Slika 2). Znaki preekscitacije $\checkmark$ EKG zapisu niso vedno vidni (3), saj je večina akcesornih poti prikritih. WPW ima številne različice (4).

Permanentna junkcijska recipročna tahikardija (PJRT) je sicer redka oblika AVRT, a jo velja omeniti, ker vztraja pri relativno nizkih srčnih frekvencah (približno 200 utripov na minuto) in je ozdravljiv razlog dilatativne kardiomiopatije v obdobju novorojenčka (1). Anterogradno prevajanje poteka preko AV vozla, retrogradno pa po posteroseptalni akcesorni poti, po kateri se upočasni $(1,3)$. V EKG zapisu ima val $P$ v spodnjih odvodih inverzno obliko (retrogradni val $P$, negativen $V$ II, III in aVF odvodu) in se pojavlja precej za kompleksom QRS (Slika 3). Ker je bližje naslednjemu kompleksu QRS (dolg interval RP), to obliko zlahka zamenjamo za AET. Pri diferencialnem diagnosticiranju je pomemben adenozinski test, ki tahikardijo le začasno prekine, saj se nato ponovno zažene. Ker je AV vozel del krogotoka, AV blok vedno vsaj kratkoročno prekine PJRT. Zdravljenje je zahtevno, saj je odzivnost na adenozin in elektrokonverzijo le začasna in pogosto terja dolgoročno zaščitno zdravljenje. Učinkovit način zdravljenja je tudi katetrska ablacija. Funkcija prekatov je motena pri 11-28 \% bolni$\operatorname{kov}(2,3)$.

\section{Atrijsko plapolanje}

Atrijsko plapolanje (angl. atrial flutter, AFL) je pogosta aritmija pri plodu in novorojenčku. $V$ kasnejšem obdobju se pojavlja izjemno redko, nato pa spet pogosteje v odraslosti. Najpogosteje se pojavlja pri strukturno nor- malnem srcu (8). Nastaja vedno po mehanizmu ponovnega vstopa (angl. re-entry). Krogotok ponovnega vstopa je umeščen znotraj preddvorov (»mikro re-entry «) in ne zajema celotnega srca. Frekvenca preddvorov je 240-360 utripov na minuto. Zapis EKG spominja na nazobčanost žage (angl. saw-tooth apearance). Čeprav se pojavlja redkeje od AVRT, pa AFL pri plodu predstavlja kar tretjino klinično pomembnih tahiaritmij (8). Hemodinamsko stanje ploda ali otroka z AFL je najbolj odvisno od bloka prevajanja, ki ga zagotavlja AV vozel (1). AFL lahko posameznik dobro prenaša oziroma poteka brez znakov, če obstaja visoka stopnja AV bloka. Prevajanje iz preddvorov $v$ prekate je najpogosteje v razmerju 2:1 (8). Če je blok prevajanja neučinkovit, se preko AV vozla prevede impulz v razmerju 1:1. Ker je običajna frekvenca atrijev približno 300 na minuto, je hemodinamska nestabilnost ob neučinkovitem bloku prevajanja neizogibna (1). Z ultrazvočno preiskavo (UZ) srca pogosto odkrijemo obojestransko preddvorno dilatacijo, ki ji sledita znižana funkcija prekatov in tudi regurgitacija zaklopk med preddvori in prekati. Adenozinski test je pomembna metoda diagnosticiranja AFL. Zaradi nastalega bloka prevajanja v AV vozlu po dajanju adenozina se demarkira več atrijskih utripov glede na število prekatnih utripov oziroma glede na pojavljanje kompleksa QRS $(4,8)$.

Zdravljenje nosečnice, ki nosi plod z AFL, je dobro raziskano in tudi uspešno (8). Najuspešnejše zdravljenje AFL pri plodu z grozečim nastankom fetalnega hidropsa je aplikacija digksina, flekainida ali sotalola nosečnici $(8,9)$. Predčasen porod in zdravljenje po rojstvu sta možnosti pri donošenih ali skoraj donošenih plodih (9). Po rojstvu najboljši izid zdravljenja dosežemo z elektrokonverzijo. Na splošno ima AFL po prekinitvi odlično napoved izida (8). Kot najuspešnejše dolgoročno antiaritmično zdravljenje navajajo propranolol, sotalol in flekainid (8).
Atrio-ventrikularna nodalna re-entry tahikardija (AVNRT)

AVNRT je veliko bolj pogosta pri starejših otrocih in odraslih. Nastane kot posledica t. i. dvojne fiziologije AV vozla, saj hkrati znotraj AV vozla obstajata dve prevodni poti, hitra in počasna. Pri najpogostejši obliki, tipični AVNRT, krogotok poteka navzdol po počasni poti in nazaj navzgor po hitri poti. Preddvori in prekati se depolarizirajo skoraj simultano, zato so valovi $\mathrm{P}$ pogosto skriti znotraj kompleksov QRS in so težko vidni oziroma so vidni retrogradni valovi P s kratkim intervalom RP. Značilnost AVRT in AVNRT je uspešna prekinitev z adenozinom ali vagalnimi manevri (1).

\section{Atrijska ektopična tahikardija (AET)}

Atrijska ektopična tahikardija pri novorojenčku je pogosta. Kaže se z ozkimi kompleksi QRS in z abnormno obliko vala P. Razmerje med valom $P$ in kompleksom QRS je variabilno in je odvisno od prevajanja preko AV vozla (1). Mehanizem v novorojenčkovem obdobju je pogosteje povečana avtomatičnost, bolj redko pa mehanizem ponovnega vstopa (»mikro re-entry«). Valovi P najpogosteje izhajajo iz enega abnormnega žarišča. Če je žarišč več, govorimo o multifokalni atrijski tahikardiji (MAT), pri kateri so valovi $P$ lahko različnih oblik. AET $v$ obdobju novorojenčka pogosto mine sama od sebe in ne zahteva zdravljenja, le spremljanje. Adenozin nanjo večinoma ne vpliva, a lahko diagnozo potrdimo $z$ adenozinskim testom $(1,4)$. Poleg abnormne oblike vala $\mathrm{P}$ in negativnega adenozinskega testa so za AET značilni fenomen segrevanja (angl. warm up phenomenon) in fenomen ohlajanja (angl. cool down phenomenon), nezmožnost vplivanja z zunanjim srčnim spodbujanjem ali kardioverzijo in variabilnost srčne frekvence $v$ odvisnosti od tonusa simpatičnega živčevja. Odgovor na zdravljenje z antiaritmiki je pogosto atipičen. Zdravljenje izbire je zaviralec receptorjev beta, v kasnejšem obdobju pa ablacija. Mul- 
tifokalna atrijska tahikardija (MAT) je bolj zahtevna za zdravljenje in pogosto zahteva zdravljenje $z$ amiodaronom. V kasnejšem obdobju sta AET in MAT lahko razlog sekundarne kardiomiopatije.

\section{Junkcijska ektopična tahikardija (JET)}

Ena izmed redkejših tahikardij je JET, ki jo zunaj enote za intenzivno terapijo srečamo redko. Izvira iz avtomatskega ektopičnega žarišča blizu AV vozla (3). Značilni so frekvenca 160-280 utripov na minuto, inverzni val P v II odvodu in kratek/odsoten interval RP. Pojavi se nekaj ur po kirurškem posegu, zlasti pri kirurški popravi defekta pretina prekatov (VSD) in Fallotove tetralogije, lahko pa ob segrevanju po zunajtelesnem krvnem obtoku. Izzveni po 48-96 urah. Približno $5 \%$ otrok je hemodinamsko ogroženih zaradi neusklajenosti utripanja med preddvoroma in prekatoma ob visoki srčni frekvenci. Zdravljenje v enoti intenzivne terapije vključuje normotermijo ali blago hipotermijo, popravo elektrolitnih motenj in hipovolemije, poglobljeno sedacijo, zniževanje odmerka inotropnih zdravil (kateholaminov), uvedbo amiodarona in začasni vklop medoperativno vstavljenega srčnega spodbujevalnika (3).

Prirojena oblika JET je pogosto družinsko pogojena. Je zahtevna za zdravljenje in ima neugodno napoved izida (3).

\section{Prekatne (ventrikularne) tahikardije (VT)}

So izredno redke v novorojenčkovem obdobju in ne sodijo v skupino SVT. Mehanizem nastanka je povečano prevajanje preko krogotoka s ponovnim vstopom. Vztrajajoča VT se lahko pojavi v sklopu obporodne hipoksije ali ob prisotnosti hamartoma. Značilen je širok kompleks QRS (pri novoroječnku > 100 $\mathrm{ms})$, pogosto ugotavljamo neusklajenost $z$ atrijsko aktivnostjo in prisotnost ujetih utripov, ki so ozki. Polimorfna VT ali ventrikularna fibrilacija (VF) se pojavljata pri kanalčkopatijah (sindrom dolge dobe QT in sindrom Brugada). Val

\section{Stanje}

obdobje novorojenčka z normalno strukturo srca

stanje s prirojeno srčno napako (PSN)
Motnja srčnega ritma

prezgodnji atrijski utripi

atrijsko plapolanje (AFL)

atrio-ventrikularna re-entry tahikardija (AVRT)

permanentna junkcijska recipročna tahikardija (PJRT)

prekatna tahikardija (VT)

blok prevajanja zaradi materinih avtoimunskih bolezni

\begin{tabular}{|c|c|}
\hline Vrsta PSN in patofiziologija & Motnja srčnega ritma \\
\hline $\begin{array}{l}\text { huda aortna stenoza } \\
\text { ishemija miokarda } \\
\text { hipertrofija levega prekata }\end{array}$ & prekatna tahikardija (VT) \\
\hline $\begin{array}{l}\text { defekt pretina preddvorov (angl. atrial } \\
\text { septum defect, ASD) } \\
\text { disfunkcija sinusnega vozla }\end{array}$ & $\begin{array}{l}\text { atrijska tahikardija } \\
\text { atrijsko plapolanje (AFL) }\end{array}$ \\
\hline $\begin{array}{l}\text { defekt pretina med preddvoroma in } \\
\text { prekatoma (angl. atrio-ventricular } \\
\text { septum defect, AVSD) } \\
\text { disfunkcija sinusnega vozla }\end{array}$ & $\begin{array}{l}\text { nadprekatna tahikardija (SVT) } \\
\text { prekatna tahikardija (VT) } \\
\text { atrio-ventrikularni blok (AV blok) }\end{array}$ \\
\hline $\begin{array}{l}\text { prirojena korigirana transpozicija } \\
\text { velikih arterij (angl. left/congenitally } \\
\text { corrected transposition of great } \\
\text { arteries, L-TGA/ccTGA) } \\
\text { številne akcesorne poti }\end{array}$ & $\begin{array}{l}\text { prirojeni atrio-ventrikularni blok (AV } \\
\text { blok) } \\
\text { prekatna tahikardija (VT) }\end{array}$ \\
\hline $\begin{array}{l}\text { D-transpozicija velikih arterij (angl. } \\
\text { D-transposition of great arteries, } \\
\text { D-TGA) }\end{array}$ & $\begin{array}{l}\text { sinusna bradikardija } \\
\text { sinu-atrialni blok } \\
\text { junkcijska ektopična tahikardija (JET) } \\
\text { prekatna tahikardija (VT) }\end{array}$ \\
\hline $\begin{array}{l}\text { Ebsteinova anomalija: } \\
\text { povečane desne srčne votline } \\
\text { prirojene akcesorne poti }\end{array}$ & $\begin{array}{l}\text { Wolf-Parkinson-Whiteov sindrom } \\
\text { atrijsko plapolanje (AFL) } \\
\text { nadprekatna tahikardija (SVT) } \\
\text { prekatna tahikardija (VT) } \\
\text { blok prevajanja }\end{array}$ \\
\hline sindrom hipoplastičnega levega srca & atrijske tahikardije \\
\hline $\begin{array}{l}\text { Fallotova tetralogija } \\
\text { disfunkcija sinoatrialnega vozla } \\
\text { preobremenitev desnega prekata }\end{array}$ & $\begin{array}{l}\text { nadprekatna tahikardija (SVT) } \\
\text { junkcijska ektopična tahikardija (JET) } \\
\text { prekatna tahikardija (VT) } \\
\text { blok prevajanja }\end{array}$ \\
\hline defekt pretina prekatov (VSD) & $\begin{array}{l}\text { junkcijska ektopična tahikardija (JET) } \\
\text { prekatna tahikardija (VT) } \\
\text { atrio-ventrikularni blok }\end{array}$ \\
\hline
\end{tabular}

stanje po

kardiokirurškem posegu

večje tveganje za pooperativno aritmijo pri bolnikih s predoperativno aritmijo največje tveganje v prvih 24 urah po operaciji (poškodba miokarda ob posegu, dodatno še hipoksija, edem in reperfuzijska poškodba)

pojavnost: $59 \%$ novorojenčkov in $79 \%$ otrok v prvih 24 urah po posegu tvegani posegi na/ob prevodnem sistemu (VSD, AVSD), posegi v prekatih (truncus arteriosus, HLHS, arterijska menjava (angl. switch))

najpogostejše: sinusna tahikardija, SVT, JET, sinusna bradikardija (AV blok) pogoste in benigne: prezgodnji atrijski utripi, prezgodnji ventrikularni utripi pozno pooperativno: atrijsko plapolanje, atrijska tahikardija

prirojene hipertrofična KMP - asimetrična prekatna tahikardija (VT)

kardiomiopatije

(KMP)

hipertrofija pretina

\begin{tabular}{|c|c|}
\hline $\begin{array}{l}\text { dilatativna KMP - dilatirani, slabo } \\
\text { krčljivi prekati }\end{array}$ & $\begin{array}{l}\text { nadprekatna tahikardija (SVT) } \\
\text { prekatna tahikardija (VT) }\end{array}$ \\
\hline $\begin{array}{l}\text { aritmogena KMP desnega prekata - } \\
\text { maščobno-fibrozno prestrukturiranje } \\
\text { stene in povečanje desnega prekata }\end{array}$ & $\begin{array}{l}\text { prezgodnji utripi prekatov (angl. } \\
\text { vetricular extrasistoles, VES) } \\
\text { prekatna tahikardija (VT) } \\
\text { prekatna fibrilacija (angl. ventricular } \\
\text { fibrilation, VF) }\end{array}$ \\
\hline
\end{tabular}

vnetne bolezni

infiltracija limfocitov, fibroze in nekroze ob virusnem miokarditisu zaradi imunsko posredovanega vnetja

možnost napredovanja v kardiomegalijo in kongestivno srčno popuščanje najpogostejši motnji srčnega ritma - prekatna tahikardija (VT) in AV blok

TABELA 1. MOTNJE SRČNEGA RITMA, KI JIH PRIČAKUJEMO PRI SPECIFIČNIH STANJIH (POVZETO PO (2)).

TABLE 1. CARDIAC ARRHYTHMIAS EXPECTED IN SPECIFIC CONDITIONS (TAKEN FROM (2)) 


\section{zdravila:}

adenozin

amiodaron

esmolol

prokainamid

propafenon

sinhronizirana elektrokonverzija

0,5-2 J/kg TT

popraviti koncentracije elektrolitov v krvi zdravila:

med pripravo na elektrokonverzijo lahko damo adenozin in izvedemo vagalne manevre

TABELA 2. PRIPOROČILA ZA ZDRAVLJENJE SVT GLEDE NA HEMODINAMSKO STANJE NOVOROJENČKA $(1,3,4,10)$. TABLE 2. RECOMMENDATIONS FOR THE TREATMENT OF SUPRAVENTRICULAR TACHYCARDIA ACCORDING TO THE NEONATE'S HAEMODYNAMIC STATE $(1,3,4,10)$.

P spremenijo komplekse QRS v obliki manjše zareze. Če obstaja hitra prevodna pot do AV vozla, pride do ventrikulo-atrijskega prevajanja v razmerju 1:1, pri čemer razlikovanje od SVT ni vedno jasno. $V$ primeru odziva na adenozin gre verjetno za SVT, a se po adenozinu prekinejo tudi nekatere VT. Diferencialna diagnoza tahikardije s širokimi kompleksi QRS vključuje VT ali SVT z blokom prevajanja ob antidromnem poteku re-entry mehanizma $(1,7)$.

\section{Dejavniki tveganja za motnje srčnega ritma pri novorojenčku}

Primarne motnje srčnega ritma se pojavljajo pri otrocih s strukturno normalnim srcem (2). Le $15 \%$ otrok, starih do 4 mesece, ima dejavnike tveganja za motnje srčnega ritma (3). Ti so:

- prirojena srčna napaka (PSN);

- kirurški poseg;

- podaljšan čas zunajtelesnega krvnega obtoka;
- elektrolitske motnje;

- volumska preobremenitev (povečan diastolni tlak z raztezanjem srčne stene ob kronični hemodinamski preobremenitvi, kongestivnem popuščanju, regurgitaciji zaklopk, vztrajajoči pljučni hipertenziji novorojenčka);

- zdravila (metilksantini, adrenalin, amfetamin, kokain);

- druge bolezni (bolezni ščitnice, miokarditis, povišana telesna temperatura);

- rabdomiomi (tuberozna skleroza).

V Tabeli 1 predstavljamo specifična stanja in pričakovane motnje srčnega ritma. Omenjamo tudi bradikardne motnje srčnega ritma, ki jih v prispevku sicer ne obravnavamo.

\section{Klinična slika tahikardij pri novorojenčkih}

Klinična slika novorojenčka z motnjo srčnega ritma je nespecifična in pogosto tudi neizrazita. Pojavijo se lahko ble- dica, cianoza, nemir, razdražljivost, težave pri hranjenju, oligurija, tahipneja, potenje in stokanje $(1-3,8)$. Za razliko od novorojenčkov se pri starejših otrocih kaže z omotico, vrtoglavico, palpitacijami, slabšo zmogljivostjo za napore in bolečinami za prsnico (8). Ob trajanju SVT vsaj 24-36 ur obstaja povečano tveganje srčnega popuščanja. Pojavi se pri $35 \%$ otrok s SVT, starih do 4 mesece (1).

\section{Zapleti pri tahikardijah in njihovem zdravljenju pri novorojenčkih}

Najpogostejši zaplet dolgotrajne epizode SVT je akutno srčno popuščanje (3) s hemodinamsko nestabilnostjo, trombemboličnim dogodkom in zaplet zaradi slabe perfuzije (npr. nekrotizirajoči enterokolitis). Pride lahko do nenadne srčne smrti, epileptičnih napadov, sinkope in pridobljene kardiomiopatije (8). Dejavniki, ki vplivajo na neugoden potek, so PSN, visoka frekvenca srca (> 180 utripov na minuto), nizka bolnikova starost in daljše trajanje SVT, čeprav se zapleti lahko pojavijo kadar koli med trajanjem aritmije $(3,8)$. Nekateri antiaritmiki imajo sami po sebi proaritmogeni učinek, saj lahko povzročijo podaljšanje dobe QT in spremembe v trajanju kompleksa QRS. Nekateri antiaritmiki toksično delujejo na jetra, pljuča in ščitnico (2).

\section{Zdravljenje nadprekatnih tahikardij pri novorojenčkih}

Začetni ukrepi so odvisni od splošnega in hemodinamskega stanja otroka. Bolj kot je hemodinamsko stanje nestabilno, bolj agresiven pristop k zdravljenju izberemo $(7,8)$. Pri novorojenčku, ki je hemodinamsko stabilen in ima SVT, so prvi ukrep vagalni manevri (polaganje ledenih obkladkov na obraz, draženje žrelnega refleksa z nazogastrično cevko) in dajanje adenozina (1). Pritiska 


\section{Zdravilo}

Adenozin

\section{Odmerek}

odmerek 50-100 $\mu \mathrm{g} / \mathrm{kg}$ hitro IV bolus ( $\mathrm{v}$ žilo, ki je čim bližje srcu, nato spiranje s fiziološko raztopino)

nato na 2 minuti povečamo za $50 \mu \mathrm{g} / \mathrm{kg}$ največji odmerek: $250 \mu \mathrm{g} / \mathrm{kg}$

\section{Neželeni učinki}

rdečica, slabost, bruhanje, razdražljivost, neudobje, bolečina za prsnico, preobčutljivostna reakcija, aritmije, premor dihanja
Pomembno

upočasni/blokira prevajanje AV vozla pripomore k diagnozi SVT z ozkimi ali širokimi QRS

demarkira AFL

minimalni hemodinamski vpliv učinek nastopi v 2 minutah zaradi kratkega $\mathrm{t} 1 / 2$ (manj kot 10 sekund)

\begin{tabular}{|c|c|c|}
\hline Amiodaron & $\begin{array}{l}5 \mathrm{mg} / \mathrm{kg} \text { IV v 20-60 minutah } \\
\text { nato } 7-15 \mu \mathrm{g} / \mathrm{kg} / \mathrm{min} \text { (10-20 mg/kg/24 } \\
\text { ur) IV } \\
\text { za infuzijo, ki traja dlje od } 1 \text { ure, naj IV } \\
\text { koncentracija ne preseže } 2 \mathrm{mg} / \mathrm{ml} \text { (sicer } \\
\text { centralni žilni pristop) } \\
\text { po } 24-48 \text { urah zdravljenja prevedba }\end{array}$ & $\begin{array}{l}\text { hipotenzija, bradikardija, pojav } \\
\text { aritmij (VF, VT, ^QTc), AV blok, } \\
\text { slabost, bruhanje, motnje v delovanju } \\
\text { ščitnice, preobčutljivostne reakcije, } \\
\text { fotosenzitivnost, periferna nevropatija, } \\
\text { optični nevritis, okvara roženice, slabost, } \\
\text { neješčnost }\end{array}$ \\
\hline
\end{tabular}

upočasni prevajanje po AV vozlu pred uvedbo korigirati koncentracijo elektrolitov dolgotrajna možnost pojava neželenih učinkov zaradi dolgega $\mathrm{t}_{1 / 2}$ (nekaj tednov) preverjanje jetrnih testov, ščitničnih hormonov na 6 mesecev peroralno zdravljenje (5-10 mg/kg/12 ur)

\begin{tabular}{lll}
\hline Propafenon & $\begin{array}{l}\text { začetni odmerek: } 2 \mathrm{mg} / \mathrm{kg} \text { IV v } 2 \text { urah } \\
\text { nato } 4-7 \mu \mathrm{g} / \mathrm{kg} / \mathrm{min}\end{array}$ & podaljšan interval QT
\end{tabular}

malo vpliva na prevajanje dokler je v terapevtskem območju, koncentracija ne vpliva na potenciranje učinka

\begin{tabular}{|c|c|c|c|}
\hline Magnezijev sulfat & $\begin{array}{l}\text { oživljanje (Torsade brez pulza): } 25-50 \text { mg/ } \\
\mathrm{kg} \text { IV/IO hitri bolus } \\
25-50 \mathrm{mg} / \mathrm{kg}(0,1-0,2 \mathrm{mmol} / \mathrm{kg}) \text {, } \\
\text { razredčen v 5-odstotni glukozi, IV v } 20 \\
\text { minutah (za stabilizacijo miokarda) }\end{array}$ & hipotenzija, bradikardija & previdnost pri ledvični okvari \\
\hline Lidokain & $\begin{array}{l}\text { začetni odmerek: 0,5-1 mg/kg IV v } 5 \\
\text { minutah } \\
\text { ponavljati na } 10 \text { minut } \\
\text { največji skupni odmerek do } 5 \mathrm{mg} / \mathrm{kg} \\
\text { nato } 10-50 \mu \mathrm{g} / \mathrm{kg} / \mathrm{min} \text { (nedonošeni: } 10 \\
\mu \mathrm{g} / \mathrm{kg} / \mathrm{min} \text { ) }\end{array}$ & $\begin{array}{l}\text { pospešitev frekvence prekatov (pri } \\
\text { AFL), hepatotoksičnost, hondroliza, } \\
\text { nevrotoksičnost (omotica, vznemirjenje, } \\
\text { bruhanje, mišični krči, konvulzije, } \\
\text { depresija dihanja, premori dihanja), } \\
\text { kardiotoksičnost (bradikardija, } \\
\text { hipotenzija, blok prevajanja) }\end{array}$ & \\
\hline Prokainamid & $\begin{array}{l}7-10 \mathrm{mg} / \mathrm{kg} \text { IV v } 30-60 \text { minutah } \\
\text { nato } 20-80 \mu \mathrm{g} / \mathrm{kg} / \mathrm{min}\end{array}$ & $\begin{array}{l}\text { hipotenzija (ob prehitri infuziji), } \\
\text { bradikardija, AV blok, VF } \\
\text { agranulocitoza, zavora kostnega } \\
\text { mozga, nevtropenija, trombocitopenija, } \\
\text { hipoplastiča anemija }\end{array}$ & $\begin{array}{l}\text { rezerviran za življenje-ogrožajoče } \\
\text { ventrikularne aritmije, neodzivne SVT } \\
\text { določati raven } \\
\text { upočasnitev prevajanja povzroči razširitev } \\
\text { kompleksov QRS (ob razširitvi več kot 35-50 } \\
\text { \% izhodiščne vrednosti ukiniti zdravljenje) }\end{array}$ \\
\hline Esmolol & $\begin{array}{l}\text { SVT: } 100 \mu \mathrm{g} / \mathrm{min} \text { v trajni infuziji; postopno } \\
\text { povečevati } 50-100 \mu \mathrm{g} / \mathrm{kg} / \mathrm{min} \text { vsakih } \\
5 \text { minut do kontrole srčne frekvence } \\
\text { (največji odmerek: } 200 \mu \mathrm{g} / \mathrm{kg} / \mathrm{min} \\
\text { VT z utripom: } 500 \mu \mathrm{g} / \mathrm{kg} \text { IV bolus }\end{array}$ & hipotenzija, flebitis & $\begin{array}{l}\text { kratkotrajno zdravljenje pooperativne } \\
\text { hipertenzije, SVT in VT } \\
\mathrm{t}_{1 / 2}: 2,8-4,5 \text { minut }\end{array}$ \\
\hline Flekainid & $\begin{array}{l}2 \mathrm{mg} / \mathrm{kg} \text { na } 12 \text { ur per os, } \\
\text { največ } 4 \mathrm{mg} / \mathrm{kg} / 12 \mathrm{ur}\end{array}$ & nefrotoksičnost & $\begin{array}{l}\text { 2-3 dni za doseganje polnega učinka } \\
\text { ima malo vpliva na prevajanje } \\
\text { ob toksičnih odmerkih ima proaritmogeni } \\
\text { učinek } \\
\text { določati ravni } \\
\text { uporaba: refraktarna SVT }\end{array}$ \\
\hline
\end{tabular}

TABELA 3. ZDRAVILA ZA ZDRAVLJENJE TAHIKARDIJ - ODMERKI IN NEŽELENI UČIN$\mathrm{KI}(4,10,11)$.

Legenda: VT - ventrikularna (prekatna) tahikardija; VF - ventrikularna (prekatna) fibrilacija; AFL - atrijsko plapolanje (angl. atrial flutter);

$\mathrm{t}_{1 / 2}$ - razpolovni čas; AV blok - atrioventrikularni blok; IV - intravensko; IO - intraosalno.
TABLE 3. ANTIARRHYTHMIC DRUGS FOR THE TREATMENT OF TACHYCARDIAS - DOS AGES AND SIDE-EFFECTS $(4,10,11)$. 
na obrite ne izvajamo več. Pri uporabi ledenih obkladkov moramo poskrbeti za preprečevanje ozeblin. Obravnava hemodinamsko nestabilnega otroka $z$ anamnezo hidropsa ploda, nedonošenosti, antenatalnega zdravljenja z zdravili in prirojene srčne napake je bolj kompleksna (1).

Hemodinamska nestabilnosti ob tahikardiji, bodisi z ozkimi bodisi s širokimi kompleksi QRS, terja takojšnjo sinhronizirano elektrokonverzijo (1). Tahikardijo s širokimi kompleksi QRS zdravimo po protokolu za VT, dokler ne dokažemo drugače (8). Priporočila za zdravljenje SVT glede na hemodinamsko stanje novorojenčka navajamo v Tabeli 2.

Izbira antiaritmičnega zdravljenja je odvisna od izkušenj z uporabo določenih zdravil v posameznem centru. $\checkmark$ Tabeli 3 predstavljamo najpogosteje uporabljena zdravila za zdravljenje tahikardij, njihovo odmerjanje in neželene učinke. Priporočila o vrstnem redu uporabe antiaritmikov se v različnih virih razlikujejo.

Razlogi neučinkovanja adenozina so lahko neprimeren odmerek, prepočasno dajanje in mehanizem tahikardije bodisi atrijska tahikardija ali VT. Če pride samo do začanega preskoka $v$ sinusni ritem, je smiselno nadaljnje zdravljenje $z$ antiaritmiki, običajno z amiodaronom, ki učinkuje tako v primeru SVT kot VT, ima majhen negativen inotropni učinek in je zato ustrezna izbira kljub zmanjšani funkciji miokarda (1).

Pooperativne aritmije se pogosto odzovejo na popravo elektrolitskih motenj, vzdrževanje normotermije, znižanje inotropnih ali vazokonstriktornih zdravil in uvedbo ustreznega antiaritmika (8).

Ker je pri novorojenčkih in otrocih do 2. leta starosti zaradi slabše razvitosti sarkoplazemskega retikuluma krčljivost miokarda odvisna od $\mathrm{Ca}^{2+}$ kanalov, se izogibamo zdravilom iz skupine zaviralcev kalcjevih kanalčkov (1).

\section{Predstavitev primera}

\section{Klinični primer 1}

27 dni stara deklica je bila napotena na Pediatrično kliniko zaradi tahikardije in okužbe zgornjih dihal. Štiri dni pred sprejemom so starši opažali pospešeno dihanje, zaspanost, odklanjanje hranjenja in manj mokre plenice. Ob tem je tako kot sorojenca kašljala in imela izcedek iz nosu. Povišane telesne temperature ni imela.

V družini niso imeli prirojenih srčnih napak ali motenj srčnega ritma, prav tako ne drugih kroničnih bolezni. Rojena je bila kot plod pete nosečnosti in tretjega poroda 33-letni zdravi materi po spontani zanositvi. Dvakrat je imela mati zgodnji spontani splav. Tokratna nosečnost je potekala normalno. Rojena je bila po spontanem začeteku poroda, vaginalno in v štirih urah. $Z$ nosečnostjo starostjo 41 tednov je bila rojena deklica kot velika za nosečnostno starost s porodno težo $4410 \mathrm{~g}$ (270 g nad 95. percentilom), porodno dolžino $54 \mathrm{~cm}$ (90. percentil). Podatka o obsegu glave nimamo. Poporodni potek je bil normalen.

Ob sprejemu je bila deklica bleda, $s$ hladnimi in marmoriranimi udi, razdražljiva, tahikardna (280 utripov na minuto), mejno tahipnoična (55 vdihov na minuto). Tehtala je $4590 \mathrm{~g}$. Kapilarni povratek je bil podaljšan (4-5 s). Vrednost krvnega tlaka je bila 80/64 $\mathrm{mmHg}$, nasičenost arterijske krvi s kisikom $100 \%$. Bila je oligurična. Imela je znake okužbe zgornjih dihal. Prekordij je bil ob palpaciji hiperdinamičen, jetra pa povečana. Femoralni pulz je bil tipen. Avskultatorno srčni šum ni bil slišen. Ostali klinični pregled je bil brez odstopanj.

EKG zapis je pokazal tahikardijo z ozkimi kompleksi QRS, utripom 250 na minuto in vidnimi retrogradnimi valovi P (Slika 1).

Z UZ srca smo ugotovili oslabljeno funkcijo levega prekata (iztisni delež $40 \%$ ) z dilatacijo. Morfologija srca je bila vide- ti normalna. Ugotovljen je bil tudi obojestranski plevralni izliv (desno $12 \mathrm{~mm}$, levo $8 \mathrm{~mm}$ ). V laboratorijskih izvidih sta izstopala povišan nespecifični biokemijski kazalnik srčega popuščanja (N-terminalni fragment prohormona možganskega tipa (NT-proBNP) > $35000 \mathrm{ng} / \mathrm{l}$ ) ter blago zvišana vrednost laktata $(4,87 \mathrm{mmol} / \mathrm{l})$. Vrednosti troponina in ščitničnih hormonov so bile primerne.

Po dvakratnem poskusu kardioverzije $\mathrm{z}$ adenozinom $\mathrm{v}$ odmerku 0,1 $\mathrm{mg} / \mathrm{kg}$ intravensko se je srčni ritem spremenil (Slika 1). V EKG zapisu po konverziji s adenozinom je bil viden sinusni ritem s frekvenco 150/min z vidno preekscitacijo (Slika 2). Zaradi ponovnega pojava tahikardije ob nemiru in aspiraciji zgornjih dihal je poleg dveh odmerkov adenozina prejela amiodaron v trajni infuziji $(6 \mu \mathrm{g} /$ $\mathrm{kg} / \mathrm{min})$, po kateri je srčni ritem kmalu postal sinusni. 12 ur po sprejemu je ponovno prišlo do tahikardije $z$ vmesnimi kratkotrajnimi preskoki v sinusni ritem, zato smo infuzijo amiodarona povečali na $10 \mu \mathrm{g} / \mathrm{kg} / \mathrm{min}$ oz. $15 \mu \mathrm{g} / \mathrm{kg} / \mathrm{min}$. Vmes je prejela skupaj pet odmerkov adenozina. Popravili smo koncentracijo magnezija in kalija ter poglobili sedacijo. Redno je prejemala furosemid vodmerku 1 $\mathrm{mg} / \mathrm{kg} / 8$ ur intravensko. Do stalnega sinusnega ritma je prišlo po 72 urah od začetka zdravljenja. Po izboljšanju funkcije levega prekata smo tretji dan uvedli zdravljenje z metoprololom $(0,45 \mathrm{mg} / \mathrm{kg} / 12$ ur peroralno). Ob normalizaciji srčnega ritma je prišlo do hitre normalizacije srčne funkcije (iztisni delež $60 \%$ ), resorpcije plevralnega izliva in zmanjšanja vrednosti pro-BNP in laktata. Infuzijo amiodarona smo postopno zniževali in po 5 dneh od začetka zdravljenja prešli na peroralno obliko in nato po 14 dneh od začetka zdravljenja prešli na končni odmerek $5 \mathrm{mg} / \mathrm{kg} /$ dan per os. Ob tem je prejemala nespremenjen odmerek metoprolola $(0,45 \mathrm{mg} /$ $\mathrm{kg} / 12$ ur peroralno). 


\section{Klinični primer 2}

14 dni star deček je bil napoten na Klinični oddelek za neonatologijo Pediatrične klinike zaradi nadprekatne tahikardije, ki so jo ugotovili ob kliničnem pregledu v porodnišnici, kamor je bil napoten za ponoven odvzem krvnih presejalnih testov. Do pregleda $v$ porodnišnici je bil brez težav. Bil je izključno dojen, za hranjenje se je zbujal sam. Redno je odvajal urin in blato. Povečane razdražljivosti, hitrega dihanja, bledice ali zaspanosti niso opažali.

Družinska anamneza je bila negativna glede srčno-žilnih in drugih kroničnih bolezni. Deček je bil plod spontane zanositve ter druge nosečnosti, ki je potekala brez posebnosti. Začetek poroda je bil spontan, potek vaginalen. Po dopolnjenih 40 tednih nosečnosti je bil rojen s porodno težo $3930 \mathrm{~g}$ (50.-90. percentil), porodno dolžino $53 \mathrm{~cm}$ (50.90. percentil) in obsegom glave $36 \mathrm{~cm}$ (50.-90. percentil). Ocena po Apgarjevi je bila 9/9 (normalno).

Ob sprejemu je tehtal 4100 g. Srčna frekvenca je znašala 230-260 utripov na minuto, nasičenost arterijske krvi s kisikom 95-99\%, vrednost arterijskega krvnega tlaka $87 / 57 \mathrm{mmHg}$. Bil je bledo-rožnat, sicer pa je bil klinični pregled v ostalem brez posebnosti. V laboratorijskih izvidih ni bilo posebnosti, vrednost laktata ni bila povišana.

V zapisu EKG smo beležili SVT s frekvenco približno 250 utripov na minuto. Viden je bil dolg interval RP z negativnimi valovi $P$ v spodnjih odvodih (Slika 3). UZ preiskava srca je pokazala strukturno in funkcijsko normalno srce. Po sprejemu je 4-krat prejel bolus adenozina intravensko $(0,1 \mathrm{mg} / \mathrm{kg} ; 0,15 \mathrm{mg} / \mathrm{kg}$; $0,2 \mathrm{mg} / \mathrm{kg}$ in $0,25 \mathrm{mg} / \mathrm{kg}$ ) in $0,2 \mathrm{mmol} /$ $\mathrm{kg}$ magnezijevega sulfata. Ob vsakem dajanju adenozina je za nekaj sekund prišlo do preskoka v sinusni ritem, nato se je ponovno po ekstrasistoli zagnala tahikardija (Slika 4). Poleg navedenih EKG značilnosti je opisani vzorec $s$ kratkotrajnim učinkovanjem adenozina na vzdrževanje sinusnega ritma značilen za PJRT. Prejel je enkratni odme-

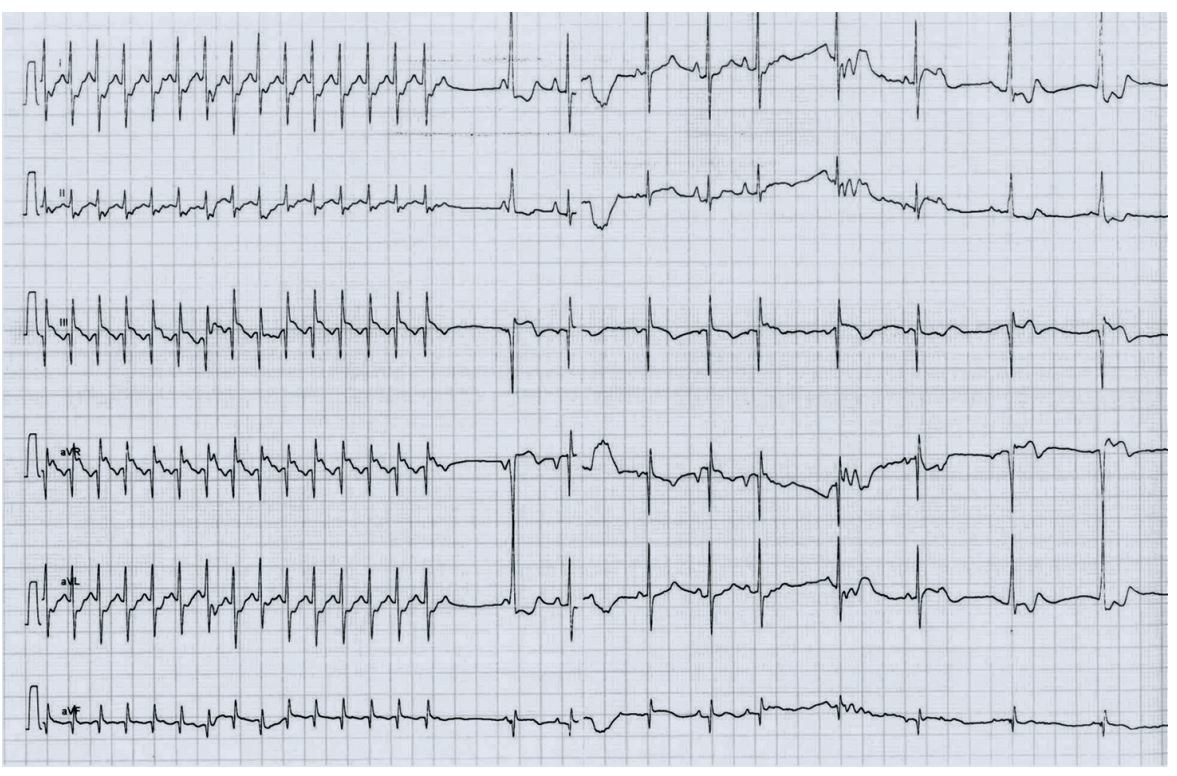

SLIKA 1. EKG OB KONVERZIJI Z ADENOZINOM - VIDNA DVA SINUSNA UTRIPA IN NATO IDIOVENTRIKULARNI RITEM. FIGURE 1. ECG AFTER ADENOSINE CARDIOVERSION -SINUS RHYTHM IS FOLLOWED BY IDIOVENTRICULAR RHYTHM.

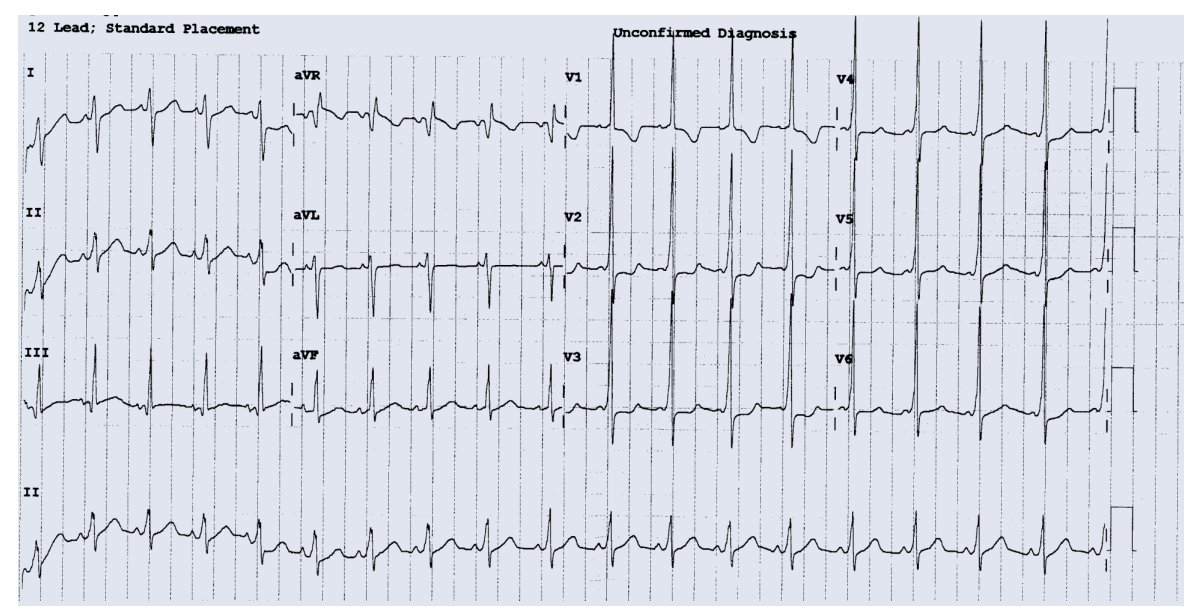

SLIKA 2. SINUSNI RITEM Z JASNIMI ZNAKI PREEKSCITACIJE.

FIGURE 2. SINUS RHYTHM WITH CLEAR SIGNS OF PRE-EXCITATION. 


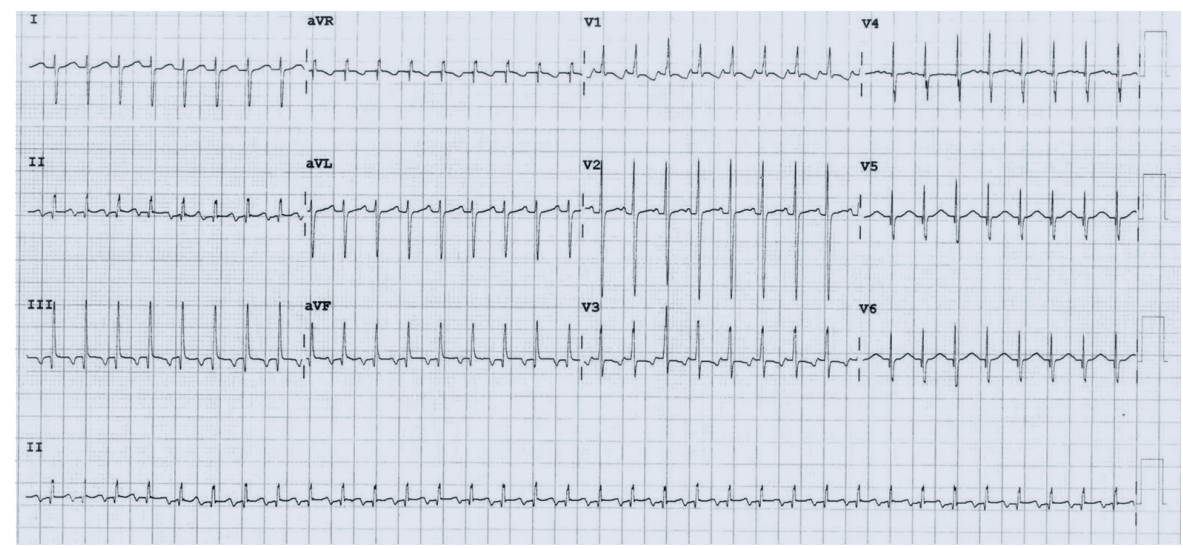

SLIKA 3. EKG OB SPREJEMU: OZEK QRS, FR. 230-250/MIN, REGULARNI INTERVALI R-R, NEGATIVNI RETROGRADNI VALOVI P V SPODNJIH ODVODIH Z DOLGIM INTERVALOM RP (PJRT), FENOMEN »P V T«.

FIGURE 3. ECG AT ADMISSION: NARROW QRS COMPLEX, PULSE 230-250 PER MINUTE, REGULAR R-R INTERVAL, NEGATIVE AND RETROGRADE P-WAVE IN THE INFERIOR LEADS WITH LONG R-P INTERVAL, »P IN T« PHENOMENON.

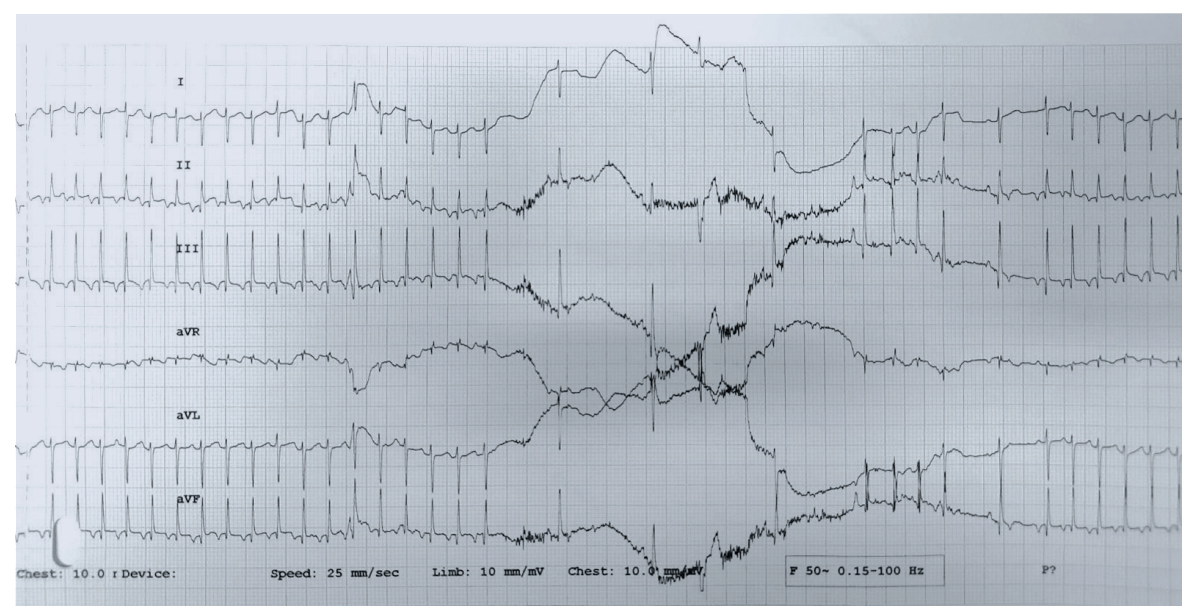

SLIKA 4. EKG OB POSKUSU KONVERZIJE Z ADENOZINOM - PREHODNI AV BLOK S KRATKOTRAJNIM PRESKOKOM V SINUSNI RITEM IN NADALJEVAN JE TAHIKARDIJE PO OBRAZCU, TIPIČNEM ZA PJRT.

FIGURE 4. AFTER ATTEMPTED ADENOSINE CONVERSION- TRANSIENT AV BLOCK, FOLLOWED BY A BRIEF PERIOD OF SINUS RHYTHM AND RELAPSE OF PJRT TACHYCARDIA. rek amiodarona $(5 \mathrm{mg} / \mathrm{kg})$, nato pa smo uvedli trajno infuzijo, sprva $7 \mu \mathrm{g} /$ $\mathrm{kg} / \mathrm{min}$, nato $15 \mu \mathrm{g} / \mathrm{kg} / \mathrm{min}$. Vmes smo trikrat vbrizgali adenozin intravensko $(0,25 \mathrm{mg} / \mathrm{kg} ; 0,3 \mathrm{mg} / \mathrm{kg}$ in $0,3 \mathrm{mg} / \mathrm{kg})$, vendar kljub vsakokratnemu začasnemu učinku do trajnega preskoka $v$ sinusni ritem ni prišlo. Uvedli smo trajno infuzijo propafenona, sprva v bolusnem odmerku $16 \mu \mathrm{g} / \mathrm{kg} / \mathrm{min}$ za 2 uri, nato pa $7 \mu \mathrm{g} / \mathrm{kg} / \mathrm{min}$ za 9 ur. V nadaljevanju je prejemal amiodaron intravensko $(11-15 \mu \mathrm{g} / \mathrm{kg} / \mathrm{min})$. Frekvenca se je nekoliko znižala (215-220/min), a ni prišlo do preskoka v sinusni ritem. 36 ur po sprejemu in začetku zdravljenja je ponovno prejel dva odmerka adenozina $(0,24 \mathrm{mg} / \mathrm{kg}$ in $0,3 \mathrm{mg} / \mathrm{kg})$. Nadaljevali smo z infuzijo amiodarona za 48 urv odmerku $15 \mu \mathrm{g} / \mathrm{kg} / \mathrm{min}$. Tretji dan po sprejemu je prišlo do nekajurnega preskoka v sinusni ritem $\mathrm{s}$ frekvenco približno 150 utripov na minuto. Odmerek amiodarona smo znižali $(7 \mu \mathrm{g} / \mathrm{kg} /$ $\mathrm{min}$ ) in v zdravljenje dodali propafenon peroralno $(2,5 \mathrm{mg} / \mathrm{kg} / 8 \mathrm{ur}$ ). Štiri dni od začetka zdravljenja je prišlo do trajnega preskoka v sinusni ritem. Dva dni po tem (tj. 6 dni po začetku zdravljenja) smo prešli na peroralno obliko amiodarona ( $5 \mathrm{mg} / \mathrm{kg} / \mathrm{dan}$ ), infuzijo pa ukinili. Zdravljenje s propafenonom smo 8 dni po začetku zdravljenja ukinili. Znakov srčnega popuščanja med hospitalizacijo ni imel. Stanje srca smo sledili z ultrazvokom, funkcija je bila ves čas primerna. Domov je bil odpuščen na zdravljenju z amiodaronom v odmerku $5 \mathrm{mg} / \mathrm{kg} /$ dan peroralno. Nadzor srčne frekvence v domačem okolju so starši pri otroku poleg opazovanja izvajali s pulznim oksimetrom. S preiskavo Holter EKG smo videli eno epizodo PJRT, ki je trajala 10 minut.

UZ preiskavi glave in trebuha sta bili normalni. Ob zdravljenju $z$ amiodaronom smo ugotovili normalen očesni status in normalno vrednost ščitničnih hormonov. Tudi presejalni testi presnove so bili normalni.

Pri starosti 6 mesecev smo zaradi odsotnosti epizod PJRT zdravljenje z znižanim odmerkom amiodarona uki- 
nili in uvedli metoprolol v odmerku 1 $\mathrm{mg} / \mathrm{kg} / 12$ ur. Do ponovne epizode tahikardije do starosti 1 leto ni prišlo.

\section{Razpravljanje}

Deklica, opisana v prvem kliničnem primeru, je imela jasne znake srčnega popuščanja in pomembno znižano srčno funkcijo, medtem ko je bil deček v drugem kliničnem primeru vitalno stabilen in brez znakov srčnega popuščanja. Pri različnih kliničnih slikah lahko sklepamo o času trajanja tahikardije - znaki srčnega popuščanja se razvijejo po 24-48 urah in so bolj izraziti pri mlajših novorojenčkih, višji srčni frekvenci, neusklajenosti med preddvori in prekati ter pri stanjih s pridruženimi boleznimi srca. Deklica iz prvega primera je prebolevala okužbo dihal, ki je dodatno vplivala na povečano obremenitev organizma in s tem tudi srčne mišice. Po normalizaciji srčnega ritma je dokaj hitro prišlo do normalizacije srčne funkcije. Nihče od predstavljenih otrok ni potreboval dodatne hemodinamske ali dihalne podpore.

Pri hemodinamsko stabilnih novorojenčkih vključenost AV vozla v krogotok s ponovnim vstopom izkoristimo $v$ terapevtske namene. Najprej z vagalnimi manevri in nato $z$ adenozinom ustvarimo začasen AV blok prevajanja, kar lahko služi za identifikacijo ali poskus prekinitve (1). Le pri otrocih s pomembno hemodinamsko nestabilnostjo ali prisotno VT se poslužujemo zunanje elektrokonverzije (0,5-2 J/kg), ki zahteva dobro sedacijo (8). SVT so v prvem letu življenja pogoste in lahko ogrožajo življenje. PJRT je eden vzrokov refraktarne SVT pri dojenčkih in malčkih. Čeprav je zahtevna za zdravljenje, je potencialno odpravljiv vzrok kardiomiopatije (5).

Diferencialna diagnoza PJRT vključuje atrijsko tahikardijo in atipično obliko AVNRT. Akcesorne poti pri PJRT so značilno umeščene v posteroseptalni regiji, kar se v EKG zapisu odraža kot negativna oblika vala $\mathrm{P} v$ spodnjih odvodih. Če je pri AET prožilno žarišče $v$ bližini AV vozla, jo na podlagi oblike valov $P$ težko razlikujemo od PJRT. PJRT se zelo pogosto ne odziva na zdravljenje $z$ antiaritmiki, saj so intervali prevajanja dolgi. Blok prevajanja se pogosto ne napravi niti $v$ anterogradni poti skozi AV vozel niti v retrogradno potekajoči akcesorni poti (12). Skupna lastnost PJRT in AET je poleg abnormne oblike vala $P$ in negativnega adenozinskega testa lahko tudi atipičen odgovor na zdravljenje $z$ antiaritmiki, zato se $v$ kasnejšem obdobju pogosto poslužujemo radiofrekvenčne ablacije (12).

Medikamentozno zdravljenje PJRT je zahtevno, pogosto refraktarno in terja večtirno zdravljenje. Glede na novejše objave (10) tahikardijo in kardiomiopatijo najbolj uspešno preprečujemo $s$ kombinacijo flekainida in amiodarona. Pri z zdravili težko obvladljivih tahikardijah priporočamo katetrsko ablacijo, ki je pri otrocih z nizko porodno težo pogosto tehnični problem. Pri majhnih otrocih, ki tehtajo manj kot $15 \mathrm{~kg}$, je poseg bolj tvegan in pogosto neuspešen, čeprav se po izsledkih zadnjih raziskav razlike pri obravnavi majhnih otrok glede varnosti in učinkovitosti v primerjavi z večjimi otroki zmanjšujejo (13).

$\checkmark$ multicentričnem retrospektivnem pregledu 194 otrok, ki so bili stari manj kot 1 leto in so imeli PJRT, je pri $18 \%$ prišlo do kardiomiopatije (6). Večino (76 \%) so zdravili samo z zdravili, 10 $\%$ pa s katetrsko ablacijo. Najpogosteje uporabljena zdravila so bili zaviralci beta-adrenergičnih receptorjev, med kombinacijami zdravil pa se je najbolj izkazala hkratna uporaba amiodarona in zaviralca beta-adrenergičnih receptorjev. Enako kombinacijo zdravil smo uporabili pri zdravljenju otroka iz drugega kliničnega primera. Najbolj uspešna monoterapija je flekainid ali propafenon. Mediana starosti ob prvem ablativnem posegu je bila 7,9 leta. Le $7 \%$ bolnikov je bilo ob prvi ablaciji mlajših od enega leta.
V nekoliko starejši retrospektivni multicentrični raziskavi (14) je bilo vključenih 85 otrok z mediano starosti 3 mesece. Približno tretjina preiskovancev je imela ob sprejemu znake srčnega popuščanja. Amiodaron in verapamil sta se izkazala kot najučinkovitejši zdravili, tako posamezno kot v kombinaciji z digoksinom. Radiofrekvenčno ablacijo so izvedli pri 18 bolnikih in pričakovano boljše rezultate dosegli pri starejših bolnikih. PJRT se je spontano razrešila pri 19 bolnikih. Starost ob pojavu PJRT ni bila napovednik spontane prekinitve tahikardije (14).

Ob primerjavi amiodarona in flekainida pri ponavljajočih se SVT pri 74 otrocih z mediano starosti 46 dni se je peroralno zdravljenje s flekainidom in amiodaronom izkazalo kot pomemben način doseganja nadzora motenj srčnega ritma (pri $81 \%$ bolnikov oziroma pri $78 \%$ bolnikov). Druga pomembna ugotovitev je bila, da je bila uspešna tudi monoterapija s flekainidom (15).

Akutna kardiokonverzija, bodisi s farmakološkimi ali nefarmakološkimi ukrepi, je običajno uspešna, a mednarodnega sklepa o učinkovitem vzdrževalnem zdravljenju še niso sprejeli. V najnovejši objavljeni retrospektivni raziskavi o farmakološkem zdravljenju SVT pri otrocih do prvega leta starosti se je najbolje izkazala kombinacija flekainida in zaviralcev beta-adrenergičnih receptorjev (sotalola ali nadolola) (16). Omenjeno zdravljenje je učinkovito pri tahikardijah, ki nastanejo po mehanizmu AVRT ali povečane avtomatičnosti. Učinkovitost flekainida, ki ga uvrščamo v skupino $1 \mathrm{C}$ antiaritmikov, je posledica zmožnosti, da upočasni hitrost depolarizacije v diastoli in ustvari bloka prevajanja tako antero- kot tudi retrogradnem prevajanju po akcesorni poti. Ima tudi dobre farmakokinetične lastnosti, saj se hitro resorbira iz prebavil in ima dolg razpolovni čas (12 ur) (16). Poskrbeti pa moramo za skrbno uvajanje in dosleden nadzor. Propafenon, ki tudi sodi v skupino $1 \mathrm{C}$, se je izkazal za učinkovito zdravilo, a manj kot flekainid (16). 
Glede na izsledke raziskav je amiodaron priporočljiv le kot zdravilo 2. reda pri zdravljenju refraktarnih SVT (16). Kljub njegovi učinkovitosti moramo poudariti možne dolgoročne neželene učinke, predvsem disfunkcijo ščitnice, ki jo v obdobju novorojenčka opisujejo pri kar $50 \%$ bolnikov, ki prejemajo omenjeno zdravljenje (17).

Čeprav je učinkovitost sotalola kot monoterapije skromna, pa ga v součinkovanju z drugimi zdravili opisujejo kot zelo uspešno zdravilo $(16,18)$. Price et al. je pri 10 bolnikih s SVT, neodzivno na dva antiaritmika, opisal nedvomno učinkovitost kombinacije flekainida in sotalola v 12 dneh od začetka zdravljenja (18).

Drugi opisani zaviralec beta-adrenergičnih receptorjev nadolol se je $v$ raziskavi izkazal kot učinkovit pristop ob hkratni uporabi flekainida (19).

Med kliničnim sledenjem obeh bolnikov, ki sta prejemala zaščitno antiaritmično zdravljenje (amiodaron in metoprolol), do ponovne epizode tahikardije ni prišlo. Pomembnih neželenih učinkov zdravil nismo beležili.

Uporaba digoksina pri preekscitacijskih sindromih (WPW) je po trenutnih priporočilih še predmet razpravljanja. Pri starejših od enega leta ga ne priporočajo več (16).

\section{Zaključek}

Postavitev diagnoze in zdravljenje motenj srčnega ritma pri novorojenčku sta za zdravnika velik izziv. $S$ čim prejšnjo postavitvijo diagnoze in zgodnjim začetkom zdravljenja lahko preprečimo potencialne življenje ogrožajoče zaplete. Na podlagi akutnega hemodinamskega stanja se odločamo o načinih zdravljenja. Izbira ustreznega antiaritmičnega zdravljenja je odvisna od resnosti klinične slike, mehanizma tahikardije in izkušenj zdravnika s posameznim zdravilom.

\section{Literatura}

1. Kothari DS, Skinner JR. Neonatal tachycardias: an update. Arch Dis Child Fetal Neonatal Ed. 2006; 91(2): F136-F144.

2. St. George-Hyslop C, Morton C, Daley E. Neonatal and Pediatric Guidelines for Arrhythmia Management. The Hospital for Sick Children, Toronto, Canada, 2014. Dostopno na: Neo_Pedia_Guidelines_Arrhythmia.pdf (pcics.org).

3. Moak JP. Supraventricular tachycardia in the neonate and infant. Prog Pediatr Cardiol 2000; 11(1): 25-38.

4. Brugada J, Blom N, Sarquella-Brugada G et al; European Heart Rhythm Association; Association for European Paediatric and Congenital Cardiology. Pharmacological and non-pharmacological therapy for arrhythmias in the pediatric population: EHRA and AEPC-Arrhythmia Working Group joint consensus statement. Europace. 2013; 15(9): 1337-82.

5. Kylat RI, Samson RA. Permanent junctional reciprocating tachycardia in infants and Children. J Arrhythm 2019; 35(3): 494-8.

6. Kang KT, Potts JE, Radbill AE, La Page MJ, Papagiannis J, Garnreiter JM, et al. Permanent junctional reciprocating tachycardia in children: a multicenter experience. Heart Rhythm 2014; 11(8): 1426-32.

7. Van Hare GF. Neonatal arrhytmias. In: Martin, R. J., In Fanaroff, A. A., \& In Walsh, M. C. Fanaroff and Martin's neonatal-perinatal medicine: Diseases of the fetus and infant. 9th Edition, 2015.

8. Woo J, Khan O, Caldarelli L, Williams P. Tachycardia in the Neonate. Pediatr Ann 2015; 44(10): e247-50.

9. Veduta A, Panaitescu AM, Ciobanu AM, et al. Treatment of Fetal Arrhythmias. J Clin Med 2021; 10(11): 2510 .

10. Srinivasan C, Balaji S. Neonatal supraventricular tachycardia. Indian Pacing Electrophysiol J 2019; 19(6): 222-31.

11. IBM Watson Health Products: Please Login [Internet]. [cited 2021 Nov 27]. Available from: https://www.micromedexsolutions.com/home/ dispatch/ssl/true

12. Kose S, Iyisoy A, Barcin C. A permanent junctional reciprocating tachycardia with atypical location, treated with radiofrequency catheter ablation. Acta Cardiol 2002; 57(5): 371-5.

13. Kato Y, Suzuki T, Yoshida Y, Ozaki N, Kishimoto S, Aoki H, Yoshida S, Watanabe S, Nakamura Y. Catheter ablation in children and patients with congenital heart disease: Review of 1021 procedures at a high-volume single center in Japan. Heart Rhythm 2020; 17(1): 49-55.

14. Vaksmann G, D'Hoinne C, Lucet V, Guillaumont S, Lupoglazoff JM, Chantepie A, et al. Permanent junctional reciprocating tachycardia in children: a multicentre study on clinical profile and outcome. Heart 2006; 92(1): 101-4.

15. Hill AC, Silka MJ, Bar-Cohen Y. A comparison of oral flecainide and amiodarone for the treatment of recurrent supraventricular tachycardia in children. Pacing Clin Electrophysiol. 2019; 42(6): 670-7.

16. Capponi G, Belli G, Giovannini M, Remaschi G, Brambilla A, Vannuccini F, et al. Supraventricular tachycardias in the first year of life: what is the best pharmacological treatment? 24 years of experience in a single centre. BMC Cardiovasc Disord 2021; 21(1): 137.
17. Creo A, Anderson H, Cannon B, Lteif A, Kumar $S$, Tebben $P$, et al. Patterns of amiodarone-induced thyroid dysfunction in infants and children. Heart Rhythm 2019; 16(9): 1436-42.

18. Price JF, Kertesz NJ, Snyder CS, Friedman RA, Fenrich AL. Flecainide and sotalol: a new combination therapy for refractory supraventricular tachycardia in children $<1$ year of age. J Am Coll Cardiol 2002; 39(3): 517-20.

19. von Alvensleben JC, LaPage MJ, Caruthers R, Bradley DJ. Nadolol for Treatment of Supraventricular Tachycardia in Infants and Young Children. Pediatric cardiology [Internet]. 2017).

Sandra Cerar, dr. med.

(kontaktna oseba / contact person)

Klinični oddelek za neonatologijo,

Pediatrična klinika, Univerzitetni klinični center Ljubljana

Bohoričeva 20, 1000 Ljubljana, Slovenija e-pošta: sandra.cerar@kclj.si

Miroslav Elek, dr. med.

Oddelek Službe za kardiologijo,

Pediatrična klinika, Univerzitetni klinični center Ljubljana, Ljubljana, Slovenija

prispelo / received: 2. 11. 2020

sprejeto / accepted: 15. 11. 2021

Cerar S, Elek M. Tahikardije pri novorojenčkih. Slov Pediatr 2021; 28(4): 189-199. https://doi. org/10.38031/slovpediatr-2021-4-02. 